\section{Smectite for Medical Use and Their Toxin Binding Capacity}

\section{Abstract}

A detoxification product (Symbio ${ }^{\circledR}$ detox), containing diosmectite, boswellia and Commiphora resin was tested in terms of its adsorption behavior. We showed that it was able to adsorb large amounts of various toxins, including heavy metals, ammonium and histamine. At $\mathrm{pH}=2.0$ is $9.5 \%$ of lead $98 \%$ of mercury and $8.8 \%$ zinc were adsorbed, while ammonium (2.5\%) remained largely unaffected. At $\mathrm{pH}$ 6.5 , we observed significantly increased adsorption for lead $(60.4 \%)$, ammonium (7.2\%) and histamine (91\%); the adsorption of zinc (11.2\%) was only slightly higher than at $\mathrm{pH}=2.0$. By contrast, the adsorption of mercury (84.6\%) was slightly lower under these conditions. The adsorption of toxic heavy metals including mercury and lead was greater than that of zinc. Thus, Symbio ${ }^{\circledR}$ detox may be used as a medical product because of its excellent binding capacity for toxins including heavy metals, ammonia and histamine. In addition, the product is not likely to result in deficiency of the essential mineral zinc. Finally, we did not detect adsorption of the pharmaceutically relevant ingredients Boswellia serrata resin and Commiphora molmol resin.

Keywords: Diosmectite; Adsorption; Heavy metals; Detox; Boswellia serrata; Commiphora molmol

Received: January 16, 2019; Accepted: February 08, 2019; Published: February 15, 2019

\section{Introduction}

The human body is constantly exposed to toxins such as flavor enhancers, food colorings, pesticides, preservatives and heavy metals that accumulate over time, giving rise to health problems. Among the physical methods used to control toxin absorption, smectite-containing products are widely recommended. Dioctahedral smectite is natural adsorbent clay formed from aluminomagnesium silicate. It is not absorbed from the gastrointestinal tract; it does not cause any systemic side-effects and is classified as a safe over-the-counter drug. Diosmectite has been effectively used in the treatment of several gastrointestinal diseases, including infectious diarrhea and food allergy [1]. In acute diarrhea in children, this effect was manifested by a reduction in the duration and frequency of liquid stools as well as in the number of cases of prolonged diarrhea. The mechanism of action of diosmectite has been proposed to involve adsorption of viruses, bacteria, and bacterial toxins as well as modification of gastrointestinal mucus [2]. The adsorptive ability of diosmectite is explained by its multilayer organization and swelling ability, creating a large surface for the exchange of molecules. In addition, the diffuse negative charges confer

\author{
Hans-Jörg Müller ${ }^{1 *}$, \\ Dorota Dobler², \\ Thomas Schmidts ${ }^{2}$ and \\ Volker Rusch ${ }^{3}$
}

1 SymbioPharm GmbH, Auf den Lüppen 10, Germany

2 RSC Pharma LTD \& Co. KG-

Anwenderzentrum für Medizintechnik der Technische Hochschule MittelhessenUniversity of Applied Science, GiessenGermany

3 SymbioGruppe GmbH \& Co KG, Auf den Lüppen 8, Germany

*Corresponding author: Hans-Jörg Müller

झ Hans-Joerg.Mueller@symbio.de

SymbioPharm GmbH, Auf den Lüppen 10, Germany.

Tel: +492772981175

Citation: Müller HJ, Dobler D, Schmidts T, Rusch V (2019) Smectite for Medical Use and Their Toxin Binding Capacity. J Food Nutr Popul Health Vol.3 No.1:16

a large adsorption capacity for mineral and organic cations [3] Diosmectite treatment may also repair mucosal integrity, as suggested by the normalization of the urinary lactulose/mannito ratio found in children with acute diarrhea [1]. Recently it was demonstrated that diosmectite had anti-inflammatory activity when administered as a post-treatment. Possible mechanisms include adsorption of luminal antigens, increased of colonic mucin levels, and potentially a direct modulatory action of cytokine production by mucosal cells [4]. Whereas diosmectite acts mostly at the physical level, several other drugs regulate gastrointestinal balance in other ways. Especially interesting are drugs based on natural products; this include, among others, Boswellia serrata and Commiphora molmol resins. Some components of boswellia, including $\beta$-boswellic acid, have been suggested as anti-inflammatory agents, as they act to inhibit serine protease cathepsin $\mathrm{G}$ and microsomal prostaglandin $\mathrm{E}$ synthase [5]. C. molmol can protect gastric mucosa against ulcers and other damage. The protective effect of $C$. $\mathrm{molmol}$ is attributed to its 
effect on mucus production; it has also been shown to increase nucleic acid and non-protein sulfhydryl concentration, possibly mediated by its free radical-scavenging, thyroid-stimulating and prostaglandin-inducing properties [6]. It has been demonstrated, that the combination of smectite with other drugs can improve their efficiency [7]. However, when using combined products, the interaction of all ingredients must be tested. In the present study a product containing diosmectite, boswellia and Commiphora resin was tested in terms of its adsorption behavior.

\section{Methods}

\section{Determination of adsorption of 3-acetyl-11- keto-boswellic acid on diosmectite}

Boswellia serrata resin was incubated with diosmectite in two ways. In both experiments the substances were incubated for $3 \mathrm{~h}$ at $37^{\circ} \mathrm{C}$ in PBS buffer $(\mathrm{pH}=6.5)$. In the first case, the two substances were incubated together. The amount of Boswellia serrata was $70 \mathrm{mg}$ and that of diosmectite was $70 \mathrm{mg}$ or $3000 \mathrm{mg}$ (two variants). After incubation, the samples were centrifuged, dried for $12 \mathrm{~h}$ at $60^{\circ} \mathrm{C}$ and subsequently incubated for $30 \mathrm{~min}$ in $5 \mathrm{~mL}$ of methanol. In the second case, both substances were incubated in a dissolution testing instrument (PT-DT7, PharmaTest Apparatebau AG, Germany) and were separated by a cellulose filter (MN 619, Macherey-Nagel). After incubation, diosmectite was dried for $12 \mathrm{~h}$ at $60^{\circ} \mathrm{C}$ and subsequently incubated for $30 \mathrm{~min}$ in $5 \mathrm{~mL}$ of methanol. Detection of 3-acetyl-11-keto-boswellic acid in the methanol-extract was performed using HPTLC method.

\section{HPTLC analysis of 3-acetyl-11-keto-boswellic acid}

The HPTLC analyses were performed on Kieselgel 60 plates (Merck, Germany) that were eluted in the ascending mode of a glass chamber with a hexane: acetone: ethyl acetate: acetic acid (5:2:2:0.5 v/v/v/v) mixture. Samples were spotted on the TLC plate $10 \mathrm{~mm}$ from the bottom edge using a Linomat $V$ semiautomatic spotter (Camag, Switzerland) and were analyzed using a TLC Scanner (Camag, Switzerland) at $250 \mathrm{~nm}$. As a reference, we used 3-acetyl-11-keto-boswellic acid (Sigma- Aldrich, Germany).

\section{Determination of adsorption of histamine on Symbio ${ }^{\circledR}$ detox}

$100 \mathrm{mg}$ histamine was incubated for $3 \mathrm{~h}$ at $37^{\circ} \mathrm{C}$ in $50 \mathrm{~mL}$ PBS buffer (pH 6.5) with $4500 \mathrm{mg}$ Symbio ${ }^{\circledR}$ detox. After incubation, the samples were centrifuged and supernatants were diluted 1:100 in PBS buffer. Histamine in the solution was determined by an ELISA method using a RIDASCREEN ${ }^{\circledR}$ Histamine Kit (R-Biopharm AG, Germany), according to the manufacturer's instructions. After the substrate reaction, optical density was measured at 450 $\mathrm{nm}$ on a plate reader (BioTek Synergy HTX, BioTek ${ }^{\circledR}$ Instruments, Inc., USA). Concentrations of histamines were calculated using guidelines from the RIDASCREEN ${ }^{\circledR}$ Kit. Ridasoft Win PC-Software was used for evaluation of the data.

\section{Determination of adsorption of heavy metals and $\mathrm{NH} 4+$ on $\mathrm{Symbio}^{\circledR}$ detox}

The metals were incubated for $90 \mathrm{~min}$ in $100 \mathrm{~mL}$ water solution at $\mathrm{pH} 2.0$ and pH 6.5 with Symbio ${ }^{\circledR}$ detox, up to $0.5 \mathrm{~g}$ of the product.
Subsequently, the suspension was centrifuged and the ions were determined in the supernatant. The concentrations of ions were $0.8 \mathrm{mg} / \mathrm{L}_{\text {for }} \mathrm{Pb}^{2+}, 0.09 \mathrm{mg} / \mathrm{L}_{\text {for }} \mathrm{Hg}^{+2}, 8 \mathrm{mg} / \mathrm{L}$ for $\mathrm{Zn}^{+2}$ and $20 \mathrm{mg} / \mathrm{L}$ for $\mathrm{NH}^{+}$. The determination of mercury $\left(\mathrm{Hg}^{2+}\right)$ was performed according to guideline DIN EN ISO 12846 [8] using the cold vaporAAS method (MWS DMA 80, MLS GmbH). The determinations of Zinc $\left(\mathrm{Zn}^{2+}\right)$ and lead $\left(\mathrm{Pb}^{2+}\right)$ were performed according to guideline DIN EN ISO 11885 [9] using inductively coupled plasma optical emission spectrometry (ICP-OES) (Varian VISTA Pro, Varian Inc.). The determination of $\mathrm{NH}^{4+}$ was performed according to guideline DIN 38406-0 [10] using photometric measurements at $655 \mathrm{~nm}$ (LP2W filter photometer, Dr. Lange).

\section{Results}

\section{Adsorption of 3-acetyl-11-keto-boswellic acid on diosmectite}

To determine the adsorption of boswellic acids on diosmectite, Boswellia serrata resin was incubated with Symbio ${ }^{\circledR}$ detox in phosphate buffer at $\mathrm{pH}=6.8$, according to the duodenal flora. As representative of boswellic acids, we quantified 3-acetyl-11keto-boswellic acid. Due to low water solubility, no boswellic acids could be detected in the solution. Independent of the incubation method, no adsorption of 3-acetyl-11-keto-boswellic acid on diosmectite was observed.

\section{Adsorption of histamine on Symbio ${ }^{\circ}$ detox}

$91.25 \%$ of histamine from the solution was adsorbed on 4500 $\mathrm{mg}$ Symbio ${ }^{\circledR}$ detox at $\mathrm{pH}=6.8$. This corresponded to an adsorption capacity of $0.19 \mathrm{mg} / \mathrm{g}$.

\section{Adsorption of heavy metals and $\mathrm{NH}_{4}^{+}$on Symbio ${ }^{\circledR}$ detox}

The adsorption of ions at $\mathrm{pH} 2.0$ and $\mathrm{pH} 6.5$ on Symbio ${ }^{\circledR}$ detox with respect to the amount of the adsorbent is presented in Figure 1. The amounts of adsorbed ions were proportionally dependent on the amount of Symbio ${ }^{\circledR}$ detox. This behavior was least noticeable for $\mathrm{Hg}^{2+}$ ions, likely due to a low concentration of the element. Hence, nearly all $\mathrm{Hg}^{2+}$ ions from the solution remained adsorbed on $0.1 \mathrm{~g}$ of $\mathrm{Symbio}^{\circledR}$ detox.

Adsorption was strongly dependent on the $\mathrm{pH}$ of the solution (Figure 1). At $\mathrm{pH}=6.5$, more $\mathrm{Pb}^{2+}, \mathrm{Zn}^{2+}$ and $\mathrm{NH}^{+}$ions were adsorbed than at $\mathrm{pH}$ 2.0. Only in the case of mercury ions was the opposite dependence observed. The strongest change in total adsorption depending on varying $\mathrm{pH}$ value was found for $\mathrm{Pb}^{2+}$ ions.

The removal efficiency and the adsorption efficiency for all tested ions are shown in Table 1. The maximum removal efficiency was obtained for $\mathrm{Hg}^{2+}$ ions and the lowest removal efficiency was obtained for $\mathrm{NH}_{4}^{+}$ions. For solutions with high ion concentration $\left(\mathrm{Zn}^{2+}, \mathrm{NH}_{4}^{+}\right)$, the adsorption efficiency was only slightly dependent on the amount of Symbio ${ }^{\circledR}$ detox. For solutions with low ion concentration $\left(\mathrm{Hg}^{2+}, \mathrm{Pb}^{2+}\right)$ the adsorption efficiency decreased with the amount of Symbio ${ }^{\circledR}$ detox. For $\mathrm{Hg}^{2+}$ ions, the adsorption efficiency decreased from $0.072 \pm 0.004$ to $0.016 \pm 0.001$ at $\mathrm{pH}$ 2.0 and from $0.064 \pm 0.001$ to $0.015 \pm 0.001$ at $\mathrm{pH}$ 6.5. For $\mathrm{Pb}^{2+}$ ions, the adsorption efficiency decreased from $0.020 \pm 0.001$ to 

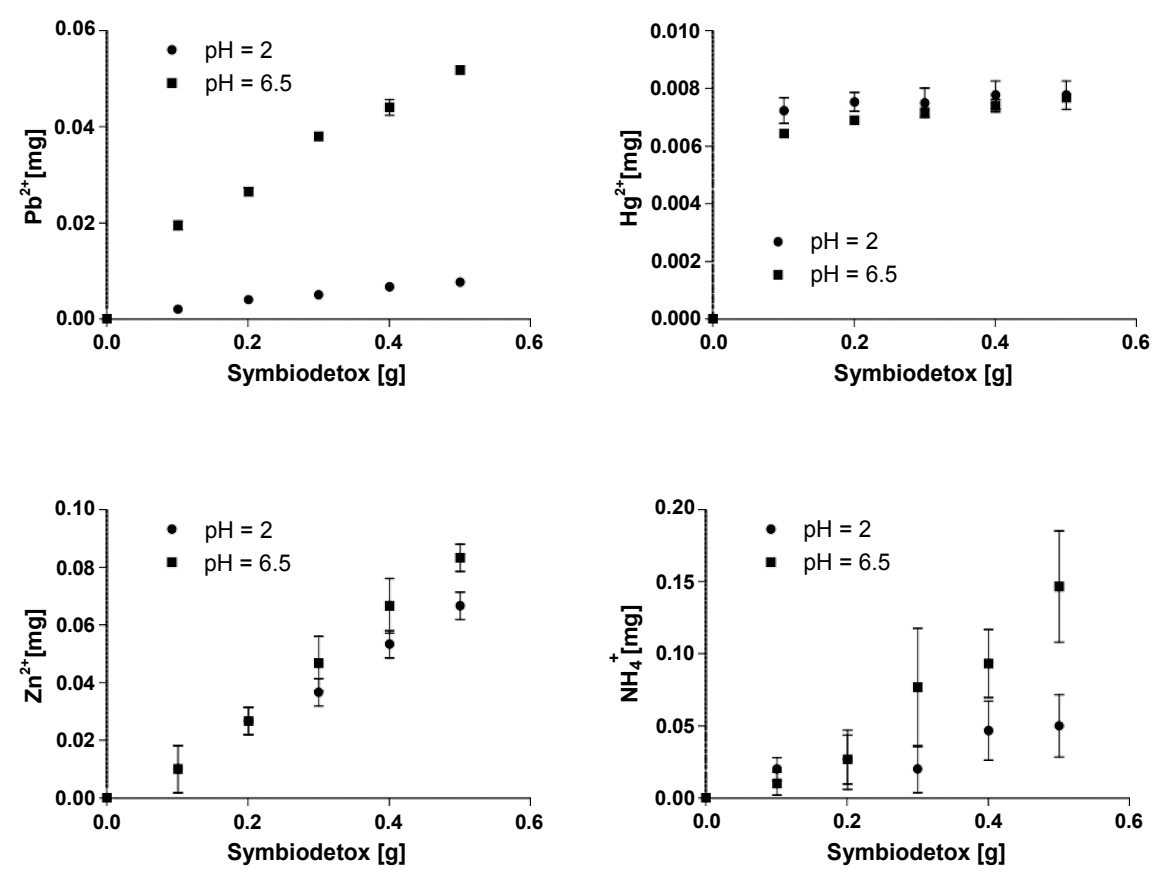

Figure 1 Adsorption of metals and $\mathrm{NH}_{4}{ }^{+}$in dependence on Symbio ${ }^{\circledR}$ detox concentration.

Table 1 Removal efficiency and adsorption efficiency relating to $0.5 \mathrm{~g}$ Symbio ${ }^{\circledR}$ detox.

\begin{tabular}{|c|c|c|c|}
\hline & $\mathbf{p H}$ & $\begin{array}{c}\text { Removal efficiency } \\
(\%)\end{array}$ & $\begin{array}{c}\text { Adsorption } \\
\text { efficiency }(\mathbf{m g} / \mathbf{g})\end{array}$ \\
\hline $\mathbf{P b}^{2+}$ & 2 & $9.5 \pm 0.6$ & $0.015 \pm 0.001$ \\
\hline $\mathrm{Zn}^{2+}$ & 6.5 & $60.4 \pm 1.1$ & $0.103 \pm 0.001$ \\
\hline $\mathbf{H g}^{2+}$ & 2 & $8.8 \pm 0.6$ & $0.133 \pm 0.009$ \\
\hline $\mathbf{N H}_{4}$ & 6.5 & $11.2 \pm 0.6$ & $0.167 \pm 0.009$ \\
& 2 & $98.7 \pm 0.1$ & $0.016 \pm 0.001$ \\
\hline & 6.5 & $84.6 \pm 1.0$ & $0.015 \pm 0.001$ \\
\hline
\end{tabular}

$0.015 \pm 0.001$ at $\mathrm{pH} 2.0$ and from $0.194 \pm 0.009$ to $0.103 \pm 0.001$ at $\mathrm{pH}$ 6.5. The adsorption capability of heavy metal ions followed the order $\mathrm{Zn}^{2+}>\mathrm{Hg}^{2+}>\mathrm{Pb}^{2+}$ at $\mathrm{pH} 2.0$ and $\mathrm{Zn}^{2+}>\mathrm{Pb}^{2+}>\mathrm{Hg}^{2+}$ at $\mathrm{pH} 6.5$ (Table 1).

\section{Discussion}

Dioctahedral smectite is natural adsorbent clay formed from fine sheets of aluminomagnesium silicate. As with most clay minerals, it is negatively charged because of the isomorphous substitution of lesser charged cations in either the octahedral or tetrahedral lattice positions [11]. The negative surface charge is satisfied by exchangeable metal cations that are retained by electrostatic forces in the interlayers or on external surfaces proximal to the surface charge sites. Water strongly interacts with smectite surfaces, primarily through hydration of the exchangeable metal cations. This leads to swelling and subsequent interlayer distance enhancement [12]. The swelling capability associated with interlayer extension is very important for the absorption potency of smectite. It allows for trapping of larger molecules, and even bacteria or viruses. In addition, the diffused negative charges confer a large adsorption capacity for mineral and organic cations [13].

Symbio ${ }^{\circledR}$ detox is a product containing smectite as well as pharmaceutically-active ingredients, including boswellic acids that regulate balance in the gastrointestinal tract. For effective action, high adsorption efficiency of toxins (such as heavy metals or histamine) and no adsorption of the enclosed pharmaceutically-active ingredients on the smectite is necessary. In the present work, we showed that organic compounds such as boswellic acids were not bound to diosmectite. This finding agrees with those of studies indicating that acidic drugs were not adsorbed onto diosmectite at $\mathrm{pH}$ 5.5-8.0, matching conditions in the gastrointestinal tract [14]. Thus, it can be expected, that the pharmaceutical activity of boswellic acids would not be influenced by the presence of smectite. By contrast, we observed adsorption of all tested metals and histamine from the solutions onto Symbio ${ }^{\circledR}$ detox. Adsorption of metal ions onto clay minerals depends on the charge characteristics of the adsorbent as well as on the metal properties of ionic charge, ionic radius, and their hard-soft acid-base characteristics. Adsorption is also affected by factors such as metal concentration, $\mathrm{pH}$, ionic strength, type and concentration of competing ions, the liquid-solid ratio and temperature [15]. Due to varying concentrations of tested substances, a direct comparison of the adsorption parameters was not possible. However, the concentrations used for metals and histamine reflect their content in foodstuffs and thus give the better overview of adsorption efficiency of Symbio ${ }^{\circledR}$ detox with regard to its detoxification properties. Mercury and lead are the most commonly occurring environmental pollutions, and their negative influence on human health is well known $[16,17]$. 
By contrast, zinc is an essential mineral involved in numerous aspects of cellular metabolism, and thus, zinc deficiency can lead to serious health problems. The removal efficiency of mercury and lead in the present experiments at $\mathrm{pH} 6.5$ was very high, up to $60.4 \%$ and $84.6 \%$ for $\mathrm{Pb}^{2+}$ and $\mathrm{Hg}^{2+}$, respectively. The removal of $\mathrm{Zn}^{2+}$ was significantly lower, approximately $11.2 \%$. The removal efficiency at $\mathrm{pH} 2.0$ was $9.5 \%$ for $\mathrm{Pb}^{2+}$ and $98.7 \%$ for $\mathrm{Hg}^{2+}$. The removal of $\mathrm{Zn}^{2+}$ in these conditions was $8.8 \%$. Adsorption onto the smectite was correlated mostly with the cation-exchange phenomena. This means that adsorption was primarily drawn to negatively-charged sites on the clays. The exchange selectivity gives rise to an order of replacement determined by the concentration of ions, their valence, and their degree of hydration and hydrated radius. Specific adsorption increases with decreasing pKa value [18]; therefore, exchange selectivity for tested metals should be as follows: $\mathrm{Hg}^{2+}>\mathrm{Pb}^{2+}$ $>\mathrm{Zn}^{2+}$. Additionally, the ion with the greater radius will be more strongly adsorbed [18]. The ionic radius sequence for tested metals was $\mathrm{Pb}^{2+}>\mathrm{Hg}^{2+}>\mathrm{Zn}^{2+}$. This dependence was also verified experimentally by other research group $[19,20]$. They found, using different clay materials, better adsorption efficiency for lead than for zinc. Additionally, the adsorption mechanism was highly $\mathrm{pH}$ dependent. Thus, we observed an increase in removal efficiency for $\mathrm{Pb}^{2+}$ and $\mathrm{Zn}^{2+}$ with increasing $\mathrm{pH}$ of aqueous solutions. Several reasons may be attributed to the increased adsorption of metal ions relative to solution $\mathrm{pH}$. The surface of smectite, containing a large number of active sites, may become positively charged at very low $\mathrm{pH}$ values. Thus, the competition between $\mathrm{H}^{+}$and metal ions for available adsorption sites increased because of increased amounts of $\mathrm{H}^{+}$in solution. However, as $\mathrm{pH}$ increases, these active surface sites become more negatively charged, enhancing the adsorption of positively-charged metal ions through an electrostatic force of attraction [21]. Conversely, increasing $\mathrm{pH}$ has been shown to decrease the solubility of metal ions. At higher $\mathrm{pH}$, the formation of hydroxyl-metal species and their precipitation in the surface region was reported $[22,23]$. The precipitation of zinc hydroxide occurs predominantly at $\mathrm{pH}>6.75$ [24], whereas this effect for lead is observed at $\mathrm{pH}>6$ [22]. Based on these data, it can be surmised that at $\mathrm{pH} 2.0$, the adsorption of the ions was associated only with ion-exchange. At pH 6.5, the remaining ion exchange was responsible for adsorption of $\mathrm{Zn}^{2+}$ ions, whereas for $\mathrm{Pb}^{2+}$ the increase of adsorption may be attributed to the precipitation of lead hydroxyl complexes. By contrast, maximum adsorption of added $\mathrm{Hg}^{2+}$ occurred at $\mathrm{pH}$ 2.0. At pH 6.5, decreased adsorption was observed. A similar effect was observed by other research groups [25]. Due to low pKa values of hydrated mercury (II), the behavior of $\mathrm{Hg}^{2+}$ was different from that of other metals. Therefore, mercury (II) at low $\mathrm{pH}$ is reduced to mercury $(\mathrm{I})$ and is hydrolyzed on the surface of the clays, resulting in greater adsorption of $\mathrm{Hg}^{2+}$ in acidic conditions. Since hydrated mercury (II) ions easily hydrolyze at higher $\mathrm{pH}$, at $\mathrm{pH} 6.5$ no precipitation of $\mathrm{HgO}$ occurs [26]. This results in decreased $\mathrm{Hg}^{2+}$ adsorption. Based on the data, it can be assumed that Symbio ${ }^{\circledR}$ detox can efficiently bind toxic heavy metals such as mercury and lead, while sufficient amount of $\mathrm{Zn}^{2+}$ is left free to be adsorbed by the gastrointestinal system. Although the ammonia molecule is a nutrient required for life, excess ammonia may accumulate in an organism and cause alteration of metabolism or increases in body $\mathrm{pH}$. Elevated levels of ammonia accompany a number of human diseases, including cirrhosis and acute liver failure, inborn errors of the urea cycle, and Reye's syndrome. Ammonia derives from the metabolism of amino acids, and especially from gluconeogenic transversion of amino acid into glucose. The intestine is a major site of ammonia production. Some $15 \%-30 \%$ of the urea synthesized by the liver is degraded by bacterial ureases in the gut, with the liberation of ammonia and carbon dioxide [27]. A second source of ammonia from the gut is the intestinal mucosa itself. The small intestine produces a substantial quantity of ammonia that is derived primarily from the metabolism of glutamine removed from arterial blood [28]. The liver is the most important site of ammonia metabolism, removing toxic ammonia by urea and glutamine synthesis [29]. However, microorganism overgrowth in the intestinal tract can produce more ammonia than the body is equipped to deal with, leading to a compromised immune system [30]. One beneficial supplement that can combat ammonia excess is clay, which absorbs toxins from the intestinal tract. In the present work, we showed that Symbio ${ }^{\circledR}$ detox effectively adsorbed $\mathrm{NH}^{+}$ions. At $\mathrm{pH} 2.0$, the relatively modest adsorption of ammonium ions depended on the quantity of Symbio ${ }^{\circledR}$ detox applied. By contrast, experiments at $\mathrm{pH} 6.5$ show marked adsorption of ammonium. More than $7 \%$ of the ammonium from the solution could be removed by $0.5 \mathrm{~g}$ of Symbio ${ }^{\circledR}$ detox. One possible explanation is that the ammonia/ammonium equilibrium $\left(\mathrm{NH}_{3} / \mathrm{NH}^{+}\right)$at $\mathrm{pH} 6.5$ is shifted in favor of ammonia $\left(\mathrm{NH}_{3}\right)$ deposited on the surface. Histamine is a biogenic amine that occurs to various degrees in many foods [31]. In healthy persons, dietary histamine can be rapidly detoxified by amine oxidases, whereas persons with low amine oxidase activity are at risk of histamine toxicity [32]. Histamine uptake by natural zeolites is one of therapeutic modalities for reducing histamine content in the intestinal tract [33]. High absorption capacity could also be shown using Symbio ${ }^{\circledR}$ detox in the present study. More than $91 \%$ of histamine could be removed from the solution.

\section{Conclusion}

The investigations at $\mathrm{pH} 2.0$ (simulated gastric milieu) showed that the Symbio ${ }^{\circledR}$ detox adsorbed lead (9.5\%), mercury (98\%) and zinc $(8.8 \%)$, while ammonium (2.5\%) remained to a great extent unaffected. At pH 6.5 (simulated duodenal flora), we observed significantly increased of adsorption of lead (60.4\%), ammonium (7.2\%) and histamine (91\%). The adsorption of zinc (11.2\%) was only slightly higher at $\mathrm{pH}$ 2.0. By contrast, the adsorption of mercury (84.6\%) was slightly lower under these conditions. The adsorption of toxic heavy metals such as mercury and lead is preferred over that of zinc. Thus, Symbio ${ }^{\circledR}$ detox may well be applied as a medical product due to its excellent binding capacity for toxins including heavy metals, ammonia and histamine. Simultaneously, deficiency of the essential mineral zinc is not highly likely. Likewise, adsorption of the pharmaceutically-active ingredients Boswellia serrata resin and Commiphora molmol resin could not be detected.

\section{Acknowledgement}

This work was supported by SymbioGruppe GmbH \& Co KG, Auf den Lüppen 8, Germany. 


\section{Declaration of Interest}

This research is sponsored by SymbioGruppe $\mathrm{GmbH}$ \& Co KG. Hans-Jörg Müller is employed by SymbioPharm $\mathrm{GmbH}$, where the studied product, Symbio ${ }^{\circledR}$ detox, is manufactured. RSC Pharma

\section{References}

1 Dupont C, Moreno JL, Barau E, Bargaoui K, Thiane E, et al. (1992) Effect of diosmectite on intestinal permeability changes in acute diarrhea: a double-blind placebo-controlled trial. J Pediatr Gastroenterol Nutr 14: 413-419.

2 Brouillard MY, Rateau JG (1989) Adsorption potency of 2 clays, smectite and kaolin on bacterial enterotoxins. In vitro study in cell culture and in the intestine of newborn mice. Gastroenterol Clin Biol 13: $18-24$

3 Suter JL, Boek ES, Sprik M (2008) Adsorption of a Sodium Ion on a Smectite Clay from Constrained Ab Initio Molecular Dynamics Simulations. J Phys Chem C 112: 18832-18839.

4 Gonzalez R, de Medina FS, Martinez-Augustin O, Nieto A, Galvez J, et al. (2004) Anti-inflammatory effect of diosmectite in hapten-induced colitis in the rat. Br J Pharmacol 141: 951-960.

5 Abdel-Tawab M, Werz O, Schubert-Zsilavecz M (2011) Boswellia serrata An Overall Assessment of In Vitro, Preclinical, Pharmacokinetic and Clinical Data. Clin Pharmacokinet 50: 349-369.

6 AlHarbi MM, Qureshi S, Raza M, Ahmed MM, Afzal M, et al. (1997) Gastric antiulcer and cytoprotective effect of Commiphora molmol in rats. J Ethnopharmacol 55: 141-150.

7 Kobyliak N, Abenavoli L, Falalyeyeva T, Beregova T (2018) Efficacy of Probiotics and Smectite in Rats with Non-Alcoholic Fatty Liver Disease. Ann Hepatol 17: 153-161.

8 Miomir Miljkovic (2012) Influence of Bitumen Emulsion and Reclaimed Asphalt on Mechanical and Pavement Design-related Performance of Asphalt Mixtures. DIN EN ISO 12846. Deutsches Institut für Normung pp: 1-205.

9 DIN EN ISO 11885 Water quality- Determination of selected elements by inductively coupled plasma atomic emission spectrometry (ICPOES) (ISO 11885: 2007); German version EN ISO 11885: 2009

10 DIN 38406-5: 1983-10 German standard methods for the examination of water, waste water and sludge; cations (group E); determination of ammonia-nitrogen (E 5)

11 Borchardt G (1989) Smectites. In Dixon JB, Weed SB, eds, Minerals in Soil Environments. Soil Sci Soc Am, Inc.

12 Minarikova M, Fojtikova V, Vyskocilova E, Sedlacek J, Sikut M, et al. (2017) The capacity and effectiveness of diosmectite and charcoal in trapping the compounds causing the most frequent intoxications in acute medicine: A comparative study. Environ Toxicol Pharmacol 52: 214-220.

13 Kraepiel AML, Keller K, Morel FMM (1999) A model for metal adsorption on montmorillonite. J Colloid Interface Sci 210: 43-54.

14 Albengres E, Urien S, Tillement JP, Oury P, Decourt S, et al. (1985) Interactions between smectite, a mucus stabilizer, and acidic and basic drugs. Eur J Clin Pharmacol 28: 601-605.

15 Ding S, Sun Y, Yang C-n, Xu B-h (2009) Removal of copper from aqueous solutions by bentonites and the factors affecting it. Mining Sci Technol (China) 19: 489-492.
LTD \& Co.KG received fees for the research. The authors assure that the methods, results, and data depicted in this paper truly reflect the procedures used and raw data collected during the studies. The authors alone are responsible for the content and writing of this paper.

16 Tchounwou PB, Ayensu WK, Ninashvili N, Sutton D (2003) Environmental exposure to mercury and its toxicopathologic implications for public health. Environ Toxicol 18: 149-175.

17 Goyer RA (1990) Lead toxicity: from overt to subclinical to subtle health effects. Environ Health Perspect 86: 177-181.

18 Pokras M (2005) Essentials of Medical Geology: Impacts of the Natural Environment on Public Health. Environ Health Perspect 113: A780-A780.

19 Jiang K, Sun T-h, Sun L-n, Li H-b (2006) Adsorption characteristics of copper, lead, zinc and cadmium ions by tourmaline. J Environ Sci18: 1221-1225.

20 Do NY, Park HI (2011) A Study on Adsorption of Pb, Cu, Zn and Cd Onto Natural Clay. Int J Environ Res 5: 413-424.

21 Unuabonah El, Olu-Owolabi BI, Adebowale KO, Ofomaja AE (2007) Adsorption of lead and cadmium ions from aqueous solutions by tripolyphosphate-impregnated Kaolinite clay. Colloids and Surfaces a-Physicochemical and Engineering Aspects 292: 202-211.

22 Griffin RA, Shimp NF (1976) Effect of pH on exchange-adsorption or precipitation of lead from landfill leachates by clay minerals. Environ Sci Technol 10: 1256-1261.

23 Farrah H, Pickering WF (1979) pH effects in the adsorption of heavy metal ions by clays. Chemical Geol 25: 317-326.

24 Frost RR, Griffin RA (1977) Effect of pH on adsorption of copper, zinc, and cadmium from landfill leachate by clay minerals. J Environ Sci Health. Part A: Environ Sci Eng 12: 139-156.

25 Yin Y, Allen HE, Li Y, Huang CP, Sanders PF (1996) Adsorption of Mercury (II) by Soil: Effects of $\mathrm{pH}$, Chloride, and Organic Matter. J Environ Quality 25: 837-844.

26 Sajidu SMI, Persson I, Masamba WRL, Henry EMT (2008) Mechanisms of heavy metal sorption on alkaline clays from Tundulu in Malawi as determined by EXAFS. J Hazard Mater 158: 401-409.

27 Jones EA, Smallwood RA, Craigie A, Rosenoer VM (1969) The enterohepatic circulation of urea nitrogen. Clin Sci 37: 825-836.

28 Weber FL Jr., Veach GL (1979) The importance of the small intestine in gut ammonium production in the fasting dog. Gastroenterol 77: 235-240.

29 Damink SWMO, Deutz NEP, Dejong CHC, Soeters PB, Jalan R (2002) Interorgan ammonia metabolism in liver failure. Neurochem Int 41 : 177-188.

30 Nakamura E, Hagen SJ (2002) Role of glutamine and arginase in protection against ammonia- induced cell death in gastric epithelial cells. Am J Physiol Gastrointestinal Liver Physiol 283: G1264-G1275.

31 Bodmer S, Imark C, Kneubuhl M (1999) Biogenic amines in foods: Histamine and food processing. Inflamm Res 48: 296-300.

32 Maintz L, Novak N (2007) Histamine and histamine intolerance. Am J Clin Nutr 85: 1185-1196.

33 Selvam T, Schwieger W, Dathe W (2014) Natural Cuban zeolites for medical use and their histamine binding capacity. Clay Minerals 49: 501-512. 